\title{
IS DE RENTESTAND GEDAALD?
}

Men heoft veel gesproken nver «de daling van den rentestand "De belangrijke artıkelen. door Prof. d'Aulnis de Bouroull hier ter plaatse aan dat onderwerp gewijd. hebben zeer de aandacht getrokken, en volkomen terecht. Over de thenris, roor dezen schrijver voorgedragen. mag men oorrleelen gelijk men wil, het is niet ain twijfel onderhevig. dat zij aanspraak heeft op een ernstig onderzock. Maar alvorens dat onderzoek begint, wensch ili cen vraag to stellen. De daling van den rentestand wil men ophelderen: roch is de rentestand workelijk gedaald? Eer men cen gebeurtenis gaat verklaren, moet men haa' nauwhemig beschrijven. en ik ben er niet zeker van. lat aan dezen eisch volkomen werd voldaan. Dat er in onzen tijd ton aanzien van de rente het een on ander is geschied, stat vast; doch wat is er goschied? IIat or een algemene daling plats, of gebourde iets amlers? Het knmt mij voor. dat er alle reden is om daarover na te denken.

Men zal mij vragen, hoe ik twijfelen kan aan de daling van de rente. nu de feiten zoo sterk en overtuigend spreken. Is het niet bekend, dat de gemiddelde prolongatickoers te Amsterdam, in 1871-75 nog 4.08, in 1876-80 3.69 , in 1881-85 3.82 pCt.. in de vier volgende jaren tot $2.62,3.08,2.66$, en 2.62 is gevallen? Dat het particulier disconto te Ionden sedert 1883 is gerlaald van gemiddeld 3.03 pCt. in dat jaal tot gemiddeld 2.35 pCt. in 1888? Dat. om een anderen en misschien nog ticon. 1890 


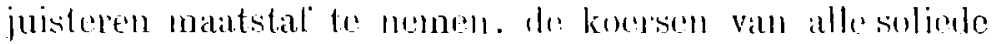
fondsen aanmerkelijk zijn gestegen. de rentr, dic men door het koopen van zulke fonrlsen makkt, dus steerls geringer went? Onze 2! pCt. Wokolijke Scludu, die in $1885 \mathrm{nog} 643$ à 693 gold. staut 13183 à 84 pCt. genoteerd, on de 3! pCt. pandbrieven van goed geaccrediteerde hypotheckbanken ziju ongeveer 100 pCt. waard. Wat anders prediken ons lie talrijle conversiën van schulden, die den kapitalisten $\%$ on on olkom zijn. dan daling van den rentestand?

Mijn antwoord hierop is. dat deze cijfers, die men naar goedvinden zou kunnen vermeerderen, het verlangde bewijs nog niet inhouden. Want zij hebben alleen betrekking op de rente, aie men bedingt door het uitleenen van kapitaal op onderpand, het in disconto nemen van handelspapier en het aaukoopen van effecten. Verder reiken zij niet. De werkelijke rente reikt wel degelijk verder. Rente wordt bedongen onder allerlei vormen, en de zoo even genoemrle zijn de talrijkste niet.

Gij koopt een voorwerp op tijd; in clen prijs is rente begrepen. Gij koopt een voorwerp contant; zelfs dan schuilt rente in den prijs, want de productie van dat voorwerp was onmogelijk zonder kapitaal, en de kapitalist heeft zijne medewerking niet kosteloos verleend. El' was ook kapitaal noodig om de werktuigen en bulpstoffen voort te brengen, die bij de productie dienst deden: niet minder dan het eerstgenoemde, vroeg het belooning. Die belooning kan hoofdbestanddeel van den prijs zijn; men denke bijvoorbeeld aan de prijzen van boomen. Om kort te gaan, niemand koopt een enkele zaak, op crediet of contant, of rente komt daarbij te pas. Rente schuilt ook in alle soorten van vrachten. Dat zij het hoofilbestanddeel is van woning-, van pakhuishuur, behoeft nauwelijks te worden aangewezen.

De rente, die in al deze vormen wordt voliaan, moet een hoogst belangrijke som uitmaken, wadlijk niet 
geringer, dan die genoten wordt uit eflecten en nitzetting van kapitaal op beleening of prolongatie. Voor een deel. wel is waar, vloeien de twee rubrieken in elkander. De koopman of fabrikant heeft soms geld noodig, dat bij opneemt ter beur'ze, of door middel van disconteering zich verschaft. Vele ondernemingen rijn naamlooze vennootschappen en hebben obligatiën uitgegeven. Op maatschappelijk gebied kan men nooit scherpe grenslijnen trekken, streng nauwkeurige onderscheidingen maken. Toch begrijpt een ieder uit het weinige, dat hier is opgemerkt, welk een fout men zou plegen door de beurs-, bank- en effectenrente zoo te beschouwen, als maakten zij de geheele rente uit. Zij zijn er slechts een gedeelte van, hoewel een niet onbelangrijk gedeelte.

Het eigenaardige nu van alle rente, die niet loor aankoop vall elfecten of uitleening van kapitaal is bedongen, bestaat hierin, dat zij nooit zelfstandig optreedt, maar altijd vermengd met andere inkomsten. De boer, die zijne koeien ter markt brengt en ze met voordeel verkoopt, geniet r'ente, want uit die koeien en het voedsel, dat hij hun gegeven heeft, bestond een gedeelte van zijn kapitaal. Kapitaal is ook de stalling, waar hij zijn vee des winters heeft geherbergd, en kapitaal had hij noodig om loon te geven aan zijne arbeiders. Doch de rente is begl'epen in zijn voordeel, dat ook loon, ondernemerswinst en pachtwaarde bevat. Het dividend, dat men trekt van een naamlooze vennootschap, bevat rente; maar het kan meer bevatten, er kan winst bij zijn. Zelfs huishuur is geen zuivere rente, want gewoonlijk is er terreinhuur onder. Hieruit wordt deze moeilijkheid geboren, dat men de rente, die door kapitaalaanwending verkregen wordt, nooit nauwkeurig kan berekenen. Haar bedrag is altijd min of meer een voorwerp van schatting, van waardeering. Bij die schatting neemt men gewoonlijk den interest tot maatstaf, die door aankoop van soliede fundsen, bijvoorbeeld van pandbrieven, wordt genoten; 
maar dit is zuiver willekeurig. Want zoodoende beslist men bij voorbaat over een vraag, die een nauwkeurig onderzoek vereischt: men neemt aan. dat de rente van de Beurs - als ik mij kortheidshalve zon mag uitdrukken - steeds gelijk moet rijn aan de rente, die in handel, nijverheid of landbouw wordt verworven. Voorts neemt men aan, dat de belooning van alle kapitaaldiensten even hoog moet zijn, hetgeen stellig onjuist is te achten: het kan zeer wel gebeuren, dat de veeboer meer rente maakt dan de katoenspinner.

Men zal waarschijnlijk reeds hebben ingezien, dat er grond is voor twijfel aangaande de daling van den rentestand. "De rente is gedaald", wordt ons gezegd. Eilieve, hoe weet gij dat? Hoe kunt gij aantoonen, dat de daling, die gij waarneemt ter Beurze, zich nog verder uitstrelit? Wat mij betreft, ik beken ronduit, dat ik dienaangaande geen licht kan geven. Zoodra ik de kapitaalrente wil nasporen buiten de geld- en buiten de effectenmarkt, vind ik haar zoodanig versmolten met andere bestanddeelen, dat hare bewegingen ontsnappen aan mijn oog.

Men zal echter vragen of tusschen die twee sonten van rente geen verband bestaat? Als de industrieel voor 3. pCt. kapitaal kan leenen, dat hem vroeger 5 pCt. kostte, zal dit hem toch een reden zijn om zijne onderneming uit te breiden: dan neemt het aanbod van kapitaaldienst in zijn tak van bedrijf allengs toe, en op de rente, die daar genoten wordt, moet dit invloed hebben! Do juistheid dezer opmerking erken ik ten volle; men kan nog meer zeggen. Wanneer door uitleening van kapitaal slechts 31 pCt. te bedingen is, waar vroeger 5 pCt. bedongen werd, bestaat er alle reden te gelooven, dat toevoeging van nieuw kapitaal aan bestaande ondernemingen of vestiging van njeuwe geacht wordt minder winstgevend te zijn dan voorheen. Ware het anders, dan zou een kapitaalvraag ontstaan, groot genoeg om lle beussente tot een hooger peil op te voeren. Dit is niet te loochumen, en op 
den langen duur moet dan ook de beursrente worden aangemerkt als viij nauwkeurig uit te drukken, niet wat in nijverheid, handel, landbouw, mijnwezen, scheepvaart, visscherij aan rente wordt verdiend, maar wat nieuwe kapitaalaanwending daar minst genomen waard is.

Ja, op den langen duur; maar deze woorden moesten hier onderstreept worden. Tijdelijk zijn groote afwijkingen denkbaar. De beursrente kan stijgen, kan dalen, terwijl de rente buiten de Beurs nagenoeg onveranderd blijft. Sterker nog: de eene kan rijzen, terwijl de andere daalt.

Er zijn tijden van levendigen ondernemingsgeest. Dan worden veel stoombooten gebouwd, veel fabrieken opgelicht, veel spoorwegen aangelegd. Niet slechts het nieuw gevormde kapitaal wordt daartoe aangewend; ook het oucle, voor zoover het beschikbaar is, levert zijn contingent. Aan de credietinstellingen worden zware eischen gedaan: zij moeten veel disconteeren, veel beleenen, en alom stijgt bij haar de rentevoet. Slechts voor een klein deel worden dan de besparingen in solieds, welbeproefde. fondsen belegd; aan deelneming in nieuwe zaken wordt de voorkeur gegeven; en het gevolg daarvan is, dat die fondsen dalen, want tegenover het aanbod. dat nooit ontbreekt, staat geen voldoende vraag. Men behoeft niet zeer oud te zijn om dikwijls zulke tijden beleefd te hebben; vooral na een vredesverdrag komen zij voor. En zij eindigen soms, schoon niet altijd, in een crisis. Of zij daarin eindigen of niet, hangt af van de mindere of meerdere behoefte, die aan nieuwe ondernemingen bestond, en van de overdrijving of gernatigdheid, waarmede die behoefte is bevredigd.

Doch er zijn andere tijden, waarin de ondernemingsgeest gering is. Het kan reactie zijn tegen vroegere opgewondenheil. Men heeft meer schepen gebouwd, meer fabrieken opgericht, meer spoorwegen aangelegd, dan voorshands met goeden uitslag geexploiteerd kunnen worden. De vrachten zijn sterk geliald, de marges tusschen 
grondstof- en fabrikaatprijzen zeer vorminderd. Hong gespannen verwachtingen werden teleurgesteld, en wie kapitaal rraagt voor nieuwe ondernemingen vindt zelılen cen goed onthaal. Even afkeerig als men vroeger was van belegging in soliede beursfondsen, even sterk geeft men nu daaraan de voorkeur. Dat zijn de schoone tijden voor staten en gemeenten, die converteeren willen, want betrouwbare waarden zijn dan bij uitstek gezocht.

Maar de oorzaak kan ook elders liggen; zij kan bestaan in appreciatie van het ruilmiddel. In dat geval doet zich een opmerkelijk ver'schijnsel voor, waarop ik de aandacht wil vestigen. het verschijnsel der denkbeeldige verliezen.

Op 1 .Tanuari van een gegeven jaar bezit gij / 100.000 aan goederen. Op 31 December hebt gij evenveel goederen, doch bij het opmaken uwer balans bespeurt gij, rat rij slechts /95000 waard zijn. Gij leidt hieruit af. dat gij f5000 op uw voorrad verloren hebt. Volkomen ten onrechte evenwel. Hadt gij een anderen waardemeter kunnen gebruiken dan geld, el zou van geen verlies hoegenaamd zijn gebleken. Want uw goederen zijn slechts in prijs, niet in ruilwaarde gedaald. Gij kunt er minder goud, mar. in doorsnede nog evenveel koopwaren voor krijgen als een jaar geleden. Inderdaad zijt niet gij zelf verarmd. maar zijn de geldbezitters eenigermate verrijkt. Met andere woorden: de $/ 95000$ zijn thans juist zooveel waard als vroeger de $/ 100000$. Dit ontsnapt echter aan uw aandacht en moest daaraan ontsnappen, want wij zijn eenmaal gewoon alles in geld te schatten en een andere wijze van schatting is moeilijk, zoo niet onmogelijk. Waardeverhooging van het geld te constateeren, is geen lichte zaak. Zelfs over de methode, naar welke dit geschieden moet, zijn de geleerden het in onze dagen nog niet met elkander eens.

Doch gemakkelijk waarneembaar of niet, geldappreciatie heett somwijlen plaats, en dan ontstaan die denkbeeldige verliezen, waarvan ik sprak. Verliezen, die ontmoedigen, 
wantrouwen wekken in industricele en andere ondernemingen, en kapitalen naal de Beurs drijven, die anders daarbuiten belegd zouden zijn.

Uit dit een en ander blijkt, naar ik meen, dat de ćnheid van den rentestand, hoewel zij op den langen duur zonder twijfel bestaat, tijdelijk niettemin zeer wel kan verbroken worden, De soliede fondsen en de belegging op prolongatie oefenen beurtelings een zeer zwakke en een zeer sterke aantrekkingskracht uit op de nieuw gevormde kapitalen, en hetzelfde laat zich getuigen van industrieele en commercieele ondernemingen. Waar de aantrekkingskracht gedurende eenigen tijd sterk is geweest, loopt zij groote kans van eerlang zwak te worden, en omgekeerd. Actie brengt reactie te weeg; dat kan bijna niet anders.

Laat bijroorbeeld een tijdlang de vraag naar soliede fondsen en het aanbod van kapitaal op prolongatie zeer levendig zijn geweest. Hiervan zullen nu twee dingen het gevolg zijn, iets negatiefs en iets positiefs. Het negatieve bestaat hierin, dat er te weinig nieuwe ondernemingen zijn tot stand gekomen. Na eenigen tijd zal dit merkbaar worden. Naamlooze vesnootschappen gaan beter'e dividenden:uitkeeren. Stoombootvrachten stijgen. Dan openbaart zich van zelf nieuw leven op allerlei gebied, waarvan meestal het eerste kenteeken is, dat ijzer en steenkolen, die twee grondzuilen der moderne nijverheid in bijkans al hare vormen, duurder worden. Wanneer dat plaats heeft, moet men altijd opmerkzaam zijn. Allicht is het een voorbode van grooter veranderingen.

Het tweede, het positieve, bestaat in het toenemen der beursspeculatie. Aanvankelijk stijgen slechts de zeer betrouwbare fondsen, doch van lieverlerle worden die zoo hoog in prijs, dat de rentenier niet meer tevreden is met het luttele inkomen, dat zij hem verschaffen. Dan vertoont zich een rijzing in hetgeen iets minder soliede wordt geacht, en het cene fonds sleept in zijne beweging 
het andere mede. Ten slotte komt (r' een h a usse-partij, die al het mogelijke doet om de hooge prijzen te bestendigen. Syndicaten hebben zich gevormd voor het tot stand brengen van conversiën en het plaatsen van leeningen, en hun belang verbiedt, dat de effektenmarkt minder vast wordt; kortom, er worden kunstmiddelen aangewend om de (ruim te van geld) aan de Beurs, die oorzaak was van de geheele beweging, te doen voortduren. Maar hoewel dit tijdelijk kan gelukken, op den duur gelukt het nooit. Ten slotte komt er cen kentering en stijgt de Beursrente. Indien de onttrekking van kapitaal aan de effekten- en prolongatiemarkt voortgaat, kan de Beursrente niet zoo laag blijven als zij was, toen aan die markt geen kapitaal werd onttrokken, maar toegevoegd.

Ik wensch mij in deze weinige bladzijden tot zuiver theoretische beschouwingen te bepalen, en waag mij dus noch aan voorspellingen, noch zelfs aan een poging tot beantwoording der vraag, hoe de verlaging der Beursrente van den jongstverloopen tijd moet worden opgevat. Ik wilde slechts doen uitkonen, dat voor het stellen dezer vraag aanleiding is te vinden. Op het meest zichtbare deel der kapitaalmarkt is le rentestand gedaald, dat is zeker; schoon het niet minder zeker is, dat in de allerlaatste maanden eenige rijzing is ingetreden, die intusschen voorbijgaand kan zijn 1). Maar strekte de daling zich ook uit tot het minder zichtbare deel? Was zij zóó algemeen, lat men mag zeggen: le rente is gedaald? Ziedaar de quaestie, die opgelost moet worden en op welker gewicht ik de aandacht wilde vestigen.

N. G. Pierson.

1) Ziehier een opgave vau het particulier wisseldisconto te Berlijn en te Lnndeu in 1884-1889, gemidileld in ieder jaar.

\begin{tabular}{|c|c|c|c|c|c|c|}
\hline & Berlijn. & Londeu. & & erlijn. & Lunder & \\
\hline 1884 & 2.82 & 2.40 percent. & 1887 & 2.30 & 2.36 & perceut. \\
\hline 1885 & 2.84 & $2 .-\quad n$ & 1888 & 2.11 & 2.35 & $n$ \\
\hline 886 & 2.05 & 2.05 & 1889 & 2.63 & 2.65 & $n$ \\
\hline
\end{tabular}

